Man and Nature

L'homme et la nature

\title{
The British Discovery of Sicily: Western Greeks and Liberty
}

Garry Retzleff

Volume 8, 1989

URI : https://id.erudit.org/iderudit/1012603ar

DOI : https://doi.org/10.7202/1012603ar

Aller au sommaire du numéro

Éditeur(s)

Canadian Society for Eighteenth-Century Studies / Société canadienne d'étude du dix-huitième siècle

ISSN

0824-3298 (imprimé)

1927-8810 (numérique)

Découvrir la revue

Citer cet article

Retzleff, G. (1989). The British Discovery of Sicily: Western Greeks and Liberty. Man and Nature / L'homme et la nature, 8, 119-128.

https://doi.org/10.7202/1012603ar

Copyright (C Canadian Society for Eighteenth-Century Studies / Sociéte canadienne d'étude du dix-huitième siècle, 1989
Ce document est protégé par la loi sur le droit d'auteur. L'utilisation des services d'Érudit (y compris la reproduction) est assujettie à sa politique d'utilisation que vous pouvez consulter en ligne.

https://apropos.erudit.org/fr/usagers/politique-dutilisation/ 


\section{The British Discovery of Sicily: Western Greeks and Liberty}

Before the 1770 's Sicily was virtually terra incognita to the ordinary British traveller. A travel book of 1701, by a certain Eli Veryard, had devoted a few pages to Sicily; ${ }^{1}$ and in 1738 John Breval had published some observations on Sicilian antiquities, noting that 'Sicily is a Ground that very few Englishmen have trod before me as Observers. ${ }^{2}$ But as late as 1770 Patrick Brydone commented that Sicily 'has never been considered as any part of the grand tour ${ }^{3}$ and described his own expedition as an attempt to escape from the old beaten track and to discover some of the interesting objects 'that must still lie buried in oblivion, in that celebrated island' $(1: 1)$.

Brydon perhaps overstated the singularity of his expedition. The trip to Sicily had been made by a few early-eighteenth-century travellers such as John Ray the botonist, Robert Milne the architect, and the young Thomas Coke, later Earl of Leicester. It is certainly true, however, that these travellers were exceptional and that most of their contemporaries saw Sicily as very remote and alien; as Denis Mack Smith has observed about eighteenth-century attitudes, most northerners 'half-accepted the idea that Europe ended at Naples, while Sicily was part of a different, semi-African world. ${ }^{4}$ There were also practical reasons for the neglect of Sicily: the badness or non-existence of roads, the lack of inns, and the supposed danger from banditti. Moreover, the lack of travel literature was itself an impediment. Eighteenthcentury travellers (like their twentieth-century counterparts) tended to follow well-established routes where they knew exactly what to see and how to respond. ${ }^{5}$

The publicizing of Sicily to the British really began in 1769, when Sir William Hamilton, Birtish envoy at the court of Ferdinand IV of Naples, made a tour of Sicily accompanied by his first wife and Lord Fortrose. Hamilton went primarily because of his interest in volcanoes, and only his record of the ascent of Etna was published. ${ }^{6}$ However, his survival of the trip - bad inns, terrible roads, and the fear of banditti notwithstanding - encouraged others to undertake expeditions to Sicily in pursuit of their interests in natural history and classical archeology. ${ }^{7}$ As tourism increased, so did travel literature: Sicilian travels were translated into English from German and Italian; and between 
1770 and 1815 well over a dozen books were written by Britons about Sicily. Some of these books were very popular and undoubtedly did much to make Sicily seem less remote and alien.

The books written about Sicily by British travellers form a very interesting body of material. From the vantage point of the twentieth century we can see that the writers' observations, like most travellers' comments, are at least as revealing about themselves as informative about the country visited. While they no doubt tried to see Sicily as it really was, the majority of them did in fact see it as an object lesson in their favourite theories of art, religion and government.

As is generally recognized, the eighteenth century began to perceive the distinction between Greek and Roman culture and to elevate the former at the expense of the latter. As a place to visit, Sicily had a privileged role in this Grecophile phase of Neo-Classicim. It had been primarily a Greek civilization from the seventh century B. C., when it was first colonized by the Greeks, until well after it became a Roman province in $242 \mathrm{~B}$. C. It was the only place with extensive remains of Greek art and civilization that was reasonably accessible to western Europeans. As late-eighteenth-century Britons could not easily visit Athens or Ionia, which were remote and under the control of the Turks, many of them went to Segesta, Agrigento and Syracuse. And in Sicily they found much to confirm their opinion that the beauty of Greek art was timeless and absolute and that its canons were ones to which all future ages should subscribe.

There was a definite progession of enthusiasm even during the period under discussion. In 1770 Brydone was much impressed by the temples at Agrigento, but was still far from seeing them as models of architectural perfection. 'The columns,' he observed, 'are shorter than the common proportions: and they are certainly not so elegant as some of the ancient temples that are to be seen about Rome, and other parts of Italy' (1:352). When Richard Payne Knight, later to become an important collector of antiquities, visted the same site in 1777, he found the temples distinguished by the utmost purity and simplicity, and conjectured that their sculpture represented what 'one of the most wealthy and magnificent of all Grecian Cities could produce in a time, when the Arts were at the highest pitch of perfection. ${ }^{8}$ Henry Swinburne, visiting Agrigento two years later, characterized the temples as among the noblest monuments of antiquity that we have left. But his most telling comment is in a footnote, where he explains that the full impact of the Grecian Doric style only struck him after he was back in Rome: 'After I returned from the country south of Naples and from Sicily, where I had seen nothing remarkable in architecture but old Doric temples, I thought the best buildings of a different style and order 
pretty, but delicate to excess. It was like turning from the transfiguration of Raphael to a miniature by Petitot. ${ }^{\prime 9}$ Similar statements on the pre-eminence of Greek architecture follow thick and fast in the succeeding books. I shall cite only Thomas Wright Vaughan, who was writing in 1810 (after the arrival of the Elgin Marbles in England had initiated the most extreme phase of Grecomania):

... the Temple of Concord [is] the most perfect of all, of incomparable symmetry, with a lightness and grandeur that can scarcely be imagined .... No building I have ever seen so completely impressed me with an idea of proportion, and of settled repose: it seemed as if the genius of the place had retired here in lofty abstraction from the degeneracy of modern efforts. Like everything good or perfect of its kind, it fills the mind completely full (if I may be allowed the expression) so that it is perfectly at rest, and seeks nothing beyond it.... ${ }^{10}$

The admiration of things Greek often extended to the Sicilians themselves. The few travel writers of the early part of the century had found little to admire about the Sicilians. Veryard had quoted with approval the apparently well-known proverb: 'All Islanders are bad, but the Sicilians are the very worst' (p. 233); this more or less summed up the pre-1769 attitude. The later travellers, though they still found much to criticize in the Sicilians, also found much to admire; and they were usually able to discover traces of the Sicilians' Greek heritage.

Typical of the classicizing of the Sicilians is Brydone's description of a country festival as evocative of pastoral poetry:

The people continued to dance, in soft Sicilan measures, till after sun-set, when they retired. The country girls are, many of them extremely handsome and dance with a good grace. The young fellows were all in their Sunday cloaths, and made a very good appearance. The assembly room, was a fine green plain on the top of a hill. It pleased us very much and put us in mind of some of Theocritus's descriptions of the Sicilian pleasures. (1:59)

There are many such comments, especially by travellers such as Sir Richard Colt Hoare ${ }^{11}$ and Thomas Watkins, ${ }^{12}$ who were particularly sensitive to the historical and literary associations of the Sicilian landscape.

Other observers discovered Greek characteristics in the physical appearance of the peasants. Thomas Hughes noted that 'amongst them is still observed that remarkable contour and beauty of countenance, called Grecian, which is so beautifully portrayed upon the ancient Sicilian coins. ${ }^{13}$ And William Thompson praised those Sicilians who 
retained their ancient dress and customs, describing them as being 'as fine a race of men as any in the world, not excepting my own countrymen. ${ }^{14}$ It was, however, female beauty which elicited their most rhapsodic admiration. Watkins, having encountered a lovely girl as toll keeper at a bridge, expressed his admiration in terms of Greek art: 'had there been ... one such woman as this, when Zeuxis painted his Juno, a single model would have been amply sufficient, or rather too much; for she is more than painting can express' (2:57). Thomas Richards was so enchanted by the serving maid at Giardini that he almost imagined 'that Grecian customs were returned to Sicily from Elysium, or that I was in a family which had preserved them for ages, pure and without any alteration. ${ }^{\prime 15}$

Of the Grecian customs that were admired, hospitality was by far the most prominent. Whereas Veryard had characterized the Sicilians as uncivil to strangers (p. 233), and Breval had told stories about their historic inhospitableness (1:6), Brydone, Knight, Swinburne and Hoare all expatiated on the Sicilians' remarkable kindness and generosity. Swinburne, for instance, tells of the night spent in a poor hovel at Calatafimi where the owners would not permit their guests to pay for anything and sat up all night to accommodate them with beds (3:357). Most of the later travellers recalled the stories perserved by Diodorus Siculus of the lavish hospitality of the Greek Sicilians, one of whom used to station a servant at the door of his house in Agrigento to invite all strangers to dine with him. It is to this story that Hoare alludes when he praises the Canonico Spoco for receiving him with the hopsitality of a Tellias (2:116). And even Richards, who periodically denounced that backwardness and brutality of the Sicilians, acknowleged that they were capable of remarkable kindness and courtesy (p. 131).

Attacks on Sicilian ignorance and superstition do continue throughout the later travel books. All of the travellers, even a Roman Catholic like Swinburne, deplored the Catanians' reliance on St. Agatha's veil rather than practical measures to protect them from the lava of Mount Etna; they also expressed amazement at the Messenians' fierce faith in the authenicity of the letter they supposedly received from the Blessed Virgin. And the majority of the travellers, being either sceptics or protestants, indicated strong disapproval of the Sicilians' fanatical devotion to their favourite saints. The writers seemed generally to agree that superstitious religiosity was more prevelant in Sicily than in any other part of Europe.

However, the so-called ignorance and superstition of the Sicilians was not attributed to any fault in themselves but rather to the oppressive and stultifying role of the church. Richards, for instance, reminded 
his readers: 'Here Seneca, Plato, Archimedes, Empedocles, Callimachus, and many other Grecian philosophers, improved mankind with their doctrines;' and he asked 'Does it not seem strange that a nation should in few centuries be so mournfully degenerated from its former state of superiority over the rest of the world?' (p. 83). He concluded that the church conspired to keep the people in slavery and ignorance (p. 85). Hughes agreed that in Sicily 'the diffusion of knowledge has been prohibited by the darkest veil that superstition ever spread before its lightening rays' (1:13). And in 1815 George Russell also recalled the glory of antiquity, remembering that in the arts and sciences 'every Sicilian city seemed almost to dispute the palm with Greece herself;' ${ }^{\prime 6}$ he lamented that modern Sicily was sunk in ignorance and avowed that 'while the clergy, as is now the case, possess an almost supreme authority over their temporal as well as their spiritual affairs, there can be no hope of improvement' (p. 258). However, Richard Payne Knight, writing just one year after the publication of the first volume of The Decline and Fall of the Roman Empire, echoed Gibbon and attacked not just the church but Christianity itself. The clergy are said to be responsible for checking 'all inquiry and improvement of every king' (p. 61), and the Christian religion for contributing to the decay of taste:

The elegant Mythology of the Greeks \& Romans, whose Deities were moral and Physical Virtues personified, afforded every possible advantage to art. Wisdom, Virtue, Majesty, Strength, \& Agility were all represented under the persons of different divinities .... When those noble Master-pieces were placed in the Temples, the People at large had an opportunity of examining their beauties \& their eyes became accustomed to elegant \& simple forms. Hence good taste became general.

But the sour Mythology of the Christian changed all. Beauty \& elegance of every kind were not only despised, but any attention to them condemned as impious \& profane. (pp. 65-66)

Thus it was to the faults of the Christian religion (among other things) that Knight attributed the corruption of taste in Sicily. Certainly it was the power of human institutions rather than any changes in national character that he blamed for the vast difference between the Sicilian Greeks and their modern descendants (p. 65).

However, a strikingly different point of view was adopted by a few of the travel writers. Brydone in particular saw Catholic superstition as continuous with the religious practices of antiquity:

The Catholics themselves do not attend to it; but it is not a little curious to consider, how small is the deviation in almost every article of their present rites from those of the ancients. I have somewhere seen an observation which 
seems to be a just one: That during the long reign of heathenism, superstition had altogether exhausted her talent for invention; and when a superstitious spirit seized Christians, they were under a necessity of borrowing from their predecessors, and imitating some part of their idolatry ....

In some places the very same images still remain: They have only christened them; and what was Venus or Proserpine is now Mary Magdalene, or the Virgin. The same ceremonies are daily performed before these images; in the same language, and nearly in the same manner. The saints are perpetually coming down in person, and working miracles, as the heathen gods did of old. The walls of the temples are covered over with the vows of pilgrims, as they were formerly .... The same incense is burned, by priests arrayed in the same manner, with the same grimaces and genuflections, before the same images, and often in the same temples too. $(1: 142-44)$

Thus, while not exactly praising the Sicilians' superstition, Brydone argued that it was at least no worse than that of their classical forbears. And after witnessing the festival of Santa Rosalia at Palermo, he began to think that superstition may not be such a bad thing; he observed that the affection the people feel for their favourite saints had something delightful in it, resembling 'the pure and delicate sensations of the most respectful love' (1:148).

What is most striking about all the writers' treatment of Sicilian superstition is that they both attack and defend it with the same polemical tool: the comparison with the practices of the ancient Greeks. This tool is also used in the extensive discussions of Sicilian government. In 1738 Breval noted the mutinous and unquiet spirit of the Sicilians and observed that their sovereigns were obliged to keep a very strict hand over them (1:6). But by the 1770's the sympathy is entirely with the mutinous Sicilians, and virtually all of the later travel writers deplore the tyranny of Spanish Bourbon rule and describe its appalling effects on the social and economic conditions of eighteenth-century Sicily. The glorious Greek past is both contrasted with the enslaved present and held up as a model for the future.

Those writing before 1789 generally restrict themselves to vague panegyrics on liberty and generalized denunciations of regal and feudal misrule. Brydone laments the poverty and oppression of the peasants of central Sicily:

Accursed tyranny - Thou worst of all curses! - what despicable objects we become in thy hands! It is really altogether inconceivable, that any government, however execrable, should be capable of rendering poor and wretched, a country that produces almost spontaneously, every thing that luxury can desire. But alas, poverty and wretchedness have ever been the attendants of 
the Spanish yoke .... Sacred liberty! Thy blessings alone are the blessings of the soul, and however small our portion, with thee it is ever sweet, but without thee, the richest gifts of nature are but so many curses - accursed be those that made them so! (2:20-21)

Swinburne and Knight particularly emphasize the contrast between present servitude and the Greek past. Swinburne says of Greek Agrigento that 'a free government, with all its happy effects, and a very active commercial spirit, exalted their commonwealth to a degree of riches and power almost unknown to the other Greek settlements' (4:3). And Knight attributes the prosperity of Greek Sicily to the independence of the various states and the resultant rivalry:

While divided into a number of little states, confined to a portion of land too small to support the Citizens, exposed to foreign invasion \& perpetually at war among themselves, their artificial wants supplied the place of natural ones, \& obliged them to be active and attentive. Arts, science and commerce flourished, \& the Spirit of emulation mutually transfer'd itself from Individuals to Societies and from Societies to Individuals; but when they were all subjected to one Power [Rome], they became secure and indolent .... \& Sicily in spite of all its advantages, sunk into Barbarism \& ignorance, which, when once established, support themselves. (p. 63)

Knight does none the less believe that 'bad however as the present state of Sicily is, it would soon recover, if the restrictions imposed by Government, were removed' (p. 63). Brian Hill, writing in 1791, is the first to make a direct comparison between Sicily and England. Having got home unmolested by banditti or the inquisition or earthquakes, he thanks God that he has returned to 'a land of peace, plenty and comfort ... where the genial sun of freedom ever shines; ${ }^{\prime 17}$ and suggests that the only hope for Sicily is for it similarly to escape from the 'dark clouds of tyranny and oppression' (p. xiv).

After 1798 the political concerns loomed much larger in the travel literature. At Christmas of that year, as French troops were invading Naples, Lord Nelson helped evacuate the royal family to Palermo. And from then until the end of the Napoleonic wars English troops and ships were stationed in Sicily in order to protect the central Mediterranean. Although the court returned to Naples briefly, it was compelled to flee to Palermo again in 1806. And, as there was no Sicilian navy or army worth the name, Ferdinand was reluctantly forced to invite the English to take over the main responsiblity for the defense of the island. By 1810 there were over 17,000 British troops in Sicily, and the British commander, in order to stabilize the political situation, used 
his influence to summon a parliament which abolished feudalism, restricted the authority of the crown and established a constitution based on the English model of government. ${ }^{18}$ That some such solution had been envisaged as early as 1798 is clear from Richards' remark that 'a great many persons in this island entertain hopes of one day being subject to the English government, and I have met with some elderly people whose only wishes are to see that day before they die' (p. 87).

For all of the early-nineteenth-century travel writers, the hope of Sicily's regaining its ancient greatness lay entirely with England. By 1810, when direct British intervention in Sicilian affairs was in progress, William Thompson, in an oblique appeal to the Greek past, observed that Sicilians were not born to be slaves, and asked if the British are to be censured if they 'at the united request of the whole people, endeavour to redress their grievances, and to assist them in recovering their ancient rights and liberties' (p. 43). Elsewhere he even more directly used the classical past to justify present action:

... [the names of] Theocritus, and of Archimedes, Charondas, of Gorgias, \&c. ... sufficiently show that the mental as well as natural improvement, or rather restoration, of Sicily, is a hope resting on the most plausible foundation, when liberty such as England possesses, and accompanied by security shall permit the expansion of intellect and nerve the arm of industry. (p. 183)

And George Russell observed that for their national rejuvenation the Sicilians needed nothing more than to establish a constitution on broad and liberal principles like those of England (p. 260). But the 'ultimate solution' was articulated by Thomas Vaughan:

Would it were possible that that which has been thought so desirable for Ireland would apply to this island! I allude to a union. Doubtless there are objections, but, were it practicable, it would seem to legitimize our army and expense for this island; and, without a single question on the subject of religion, it would rivet the people .... [and] the constitution of the country would come back to what it was, and that entre nous is what the people desire. (p. xlvi)

The pleas for intervention in Sicilian affairs, coupled with the frequent allusions to the ancient liberties of Greek Sicily, illustrate a curiously egocentric aspect of British Neo-Classicism. The British began visiting Sicily to become familiar with the great monuments of Greek art to be found there; the love the Greek past predisposed them to see at least some classical virtues in contemporary Sicilians and Sicilian society; however, they ended up occupying the island, interfering in its government, and planning to make it part of the British empire - 
justifying every step by reference to that same Greek heritage. They clearly believed that although Greek art and ancient customs might be preserved in Sicily, the Greek ideal of liberty had been realized only in Britain.

\section{GARRY RETZLEFF}

Bishop's University

\section{Notes}

1 An account of Divers Choice Remarks, as Well Geographical as Historical, Political, Mathematical, Physical, and Moral; Taken in a Journey through the Low Countries, Grance, Italy and Part of Spain; with the Isles of Sicily and Malta (London, 1701).

2 Remarks on Several Parts of Europe, Relating Chiefly to Their Antiquities and Their History (London, 1738), 1:iv.

3 A Tour Through Sicily and Malta, 2 vols. (London, 1773), 1:3.

4 A History of Sicily: Modern Sicily after 1713 (New York: Viking, 1968), p. 304.

5 For a discussion of the conventional itineraries cf. William Edward Mead, The Grand Tour in the Eighteenth Century (Boston: Houghton Mifflin, 1917); Jeremy Black notes the rarity and difficulty of travel to Sicily in The British and the Grand Tour (London: Croom Helm, 1985), pp. 22-24.

6 Observations on Mount Vesuvius, Mount Etna, and Other Volcanos, in a Series of Letters Addressed to the Royal Society (London, 1772).

7 See Black, pp. 23 and 226.

8 Expedition into Sicily, ed. Claudia Stumpf (London: British Museum, 1986), p. 44.

9 Travels in the Two Sicilies, 2nd ed., 4 vols. (London, 1790), 3:201n.

10 'Extracts from Various Letters Written in Sicily in 1809 and 1810,' in A View of the present State of Sicily, by Abbate Balsamo (London, 1811), p. lxxiv.

11 A Classical Tour through Italy and Sicily, 2nd ed., 2 vols. (London: 1819). The tour was made in 1790 .

12 Travels through Switzerland, Italy, Sicily, the Greek Island, to Constantinople (London, 1792).

13 Thomas Smart Hughes, Travels in Sicily, Greece and Albania, 2 vols. (London: 1820), p. 30. Hughes visited Sicily in 1813.

14 Sicily and Its Inhabitants: Observations Made During a Residence in That Country, in the Years 1809 and 1810 (London, 1813), p. 101. 
15 Letters from Sicily Written in the Year 1798 (London, 1811), p. 37.

16 A Tour through Sicily in the Year 1815 (London, 1819), p. 43.

17 Observations and Remarks in a Journey through Sicily and Calabria, in the Year 1791 (London, 1792), p. xiv.

18 Cf. Smith, pp. 335-352. 